\title{
Faktor-Faktor yang Mempengaruhi Pemerolehan Bahasa Kedua
}

\author{
Yuliana Sesi Bitu
}

Program Studi Pendidikan Bahasa Indonesia, STKIP Weetebula.

\author{
*Yuliana Sesi Bitu: \\ Program Studi Pendidikan \\ Bahasa Indonesia; \\ STKIP Weetebula; Email: \\ sesibitu@gmail.com
}

\begin{abstract}
Abstrak: Artikel ini bertujuan untuk membahas faktor-faktor yang mempengaruhi pemerolehan bahasa kedua. Metode yang digunakan untuk mendapatkan data tentang faktor-faktor yang mempengaruhi pemerolehan bahasa kedua adalah metode kajian pustaka, wawancara dan observasi. Studi pustaka digunakan untuk mengkaji buku-buku teks dan bahan informasi dari internet serta jurnal yang relevan dengan topik kajian. Metode wawancara dan observasi digunakan untuk mendapat data-data sebagai bukti adanya faktorfaktor yang mempengaruhi pemerolehan bahasa kedua. Berdasarkan hasil penelitian ditemukan bahwa faktor usia, lingkungan dan kebiasaan, struktur bahasa pertama terhadap pemerolehan bahasa kedua dan motivasi sangat mempengaruhi pemerolehan bahasa kedua.
\end{abstract}

Kata Kunci: Bahasa pertama, bahasa kedua, faktor-faktor yang mempengaruhi pemerolehan bahasa kedua, Pemerolehan bahasa.

Abstract: This article aims to discuss the factors that influence the acquisition of a second language. The method used to obtain data to discuss the factors that influence the acquisition of a second language is the method of literature review, interviews and observation. Library study is used to review text books and information materials from the internet and journals that are relevant to the topic of the study. Interview method is used to get the data as evidence of factors that influence the acquisition of a second language. From the result of the research, it is found that age, environment and habit factor, first language structure on second language acquisition and motivation greatly influence second language acquisition.

Key word: First language, factors influencing the acquisition of a second language, language acquisition, second language.

\section{Pendahuluan}

Bahasa merupakan alat komunikasi yang digunakan oleh manusia untuk berinteraksi dengan sesamanya. Dengan bahasa, manusia bisa berbagi ilmu pengetahuan, berbagi ide, bertukar informasi dan memahami orang lain. Dengan kata lain, manusia akan mampu menguasai atau memperoleh bahasa selagi dia hidup, tumbuh dan berkembang. Upaya penguasaan bahasa dapat dilakukan melalui dua cara, yaitu pengajaran bahasa dan pemerolehan bahasa. Pengajaran bahasa merupakan proses penguasaan bahasa seseorang yang dilakukan dalam situasi formal dan terbatas pada tataran makna atau kaidahkaidah kebahasaan. Pengajaran bahasa mengacu pada penguasaan bahasa secara sadar. Sedangkan, pemerolehan bahasa merupakan proses penguasaan bahasa seseorang yang dilakukan dalam situasi nonformal yang berupaya memahami bahasa pada tataran maksud dengan mengaitkannya dengan konteks. Pemerolehan bahasa merupakan suatu strategi pemerolehan bahasa yang berusaha menguasai bahasa secara kompleks. Pemerolehan mengacu pada penguasaan bahasa secara tidak disadari dan tidak dipengaruhi oleh pengajaran tentang kaidah dan struktur kebahasaan serta lingkungan yang formal.

Pembelajaran bahasa difokuskan pada penguasaan bahasa dalam bentuk tertulis. Tujuannya adalah agar pelajar memahami struktur dan aturan bahasa, membedahnya serta menganalisisnya, selain itu diperlukan usaha intelektual dan penalaran deduktif kepada para pelajar. Pendekatan dalam bentuk pembelajaran, memiliki ciri. Pertama, mengesampingkan komunikasi, komunikasi di anggap tidak begitu penting. Kedua, teknik belajar mengajar hanya bersandar pada silabus, hal ini akan memberi kesan kaku dan kurang imajinatif. Ketiga, banyak 
berkutat hanya pada teori, aturan-aturan kebahasaan dan tidak dibarengi dengan praktik. Keempat, guru memiliki otoritas utama, pelajar hanya sebagai participant, bergerak secara pasif. Kelima, pelajar hampir tidak pernah menguasai penggunaan struktur dalam percakapan (Adero, 2013).

Krashen (Adero, 2013) mengatakan bahwa pemerolehan merupakan proses alami yang berlangsung tanpa adanya perhatian secara sadar terhadap bentuk-bentuk linguistik; kondisi minimal pemerolehan ialah partisipasi dalam situasi komunikasi yang alami. Adapun pembelajaran bahasa merupakan proses yang terjadi secara sadar yang oleh Krashen ditandai dengan dua karakteristik, yaitu adanya umpan balik dan pengisolasian kaidah.

Penguasaan sebuah bahasa oleh seseorang dimulai dengan pemerolehan bahasa pertama yang sering kali disebut bahasa ibu (B1). Pemerolehan bahasa pertama biasanya dikaitkan dengan pemerolehan bahasa seorang anak yang terjadi pertama kali dalam lingkungan keluarga dengan cara menirukan bahasa, pada proses ini, anak tidak menyadari bahwa dia mempelajari bahasanya. Setelah menguasai bahasa pertama (B1), seseorang dalam proses selanjutnya bisa memperoleh bahasa lainnya atau biasa disebut bahasa kedua (B2) dengan tujuan untuk memperluas pengetahuan, meningkatkan kemampuan berkomunikasi, dapat beradaptasi dengan dunia luar dan guna mengembangkan kehidupannya. Seseorang juga berusaha memperoleh bahasa kedua sebagai bahasa yang dapat digunakan dalam kehidupan sehari-harinya untuk berbagai kepentingan. Misalnya, kepentingan pariwisata, pendidikan, pekerjaan, ekonomi, sosial, budaya, dan politik.

Pemerolehan bahasa kedua (B2) tentu saja memerlukan proses. Kefasihan seseorang dalam menggunakan bahasa kedua sangat tergantung pada adanya kesempatan untuk menggunakan bahasa kedua itu dan faktor-faktor lain yang mempengaruhi pemerolehan bahasa kedua, misalnya pengaruh bahasa pertama dan bahasa kedua, lingkungan, usia, budaya dan media. Untuk memperoleh pemahaman yang mendalam tentang pemerolehan bahasa kedua dan faktor-faktor yang mempengaruhinya, maka dalam artikel ini akan memaparkan beberapa hal yang berkaitan dengan pemerolehan bahasa dan faktor-faktor yang mempengaruhi pemerolehan bahasa kedua.

\section{Metode}

Penelitian ini termasuk dalam jenis penelitian deskriptif kualitatif. Penelitian kualitatif adalah penelitian yang penting untuk memahami suatu fenomena sosial dan perspektif individu yang diteliti. Tujuan pokoknya adalah menggambarkan, mempelajari, dan menjelaskan fenomena tersebut (Syamsudin dan Damaianti, 2009: 74).

Metode pengumpulan data yang digunakan dalam penelitian ini adalah studi pustaka, wawancara dan observasi. Studi pustaka digunakan dengan maksud untuk mengkaji bukubuku teks dan bahan informasi dari internet serta jurnal yang relevan dengan topik yang diteliti. Metode wawancara dan observasi digunakan untuk mendapat data-data sebagai bukti adanya faktor-faktor yang mempengaruhi pemerolehan bahasa kedua.

Teknik analisis data yang digunakan dalam penelitian ini menggunakan model analisis data yang dikemukakan Miles dan Huberman (1992) dalam Sugiono (2005:91), yaitu reduksi data, penyajian data, penarikan kesimpulan dan verifikasi data.

\section{Hasil dan Pembahasan \\ Pemerolehan Bahasa}

Pemerolehan bahasa adalah proses penguasaan bahasa seseorang yang terjadi secara alamiah atau tidak disadari dan tidak dipengaruhi oleh pengajaran tentang kaidah dan struktur kebahasaan serta lingkungan yang formal. Istilah pemerolehan bahasa biasanya digunakan pada anak-anak yang belum pernah belajar bahasa apapun dan mulai belajar bahasa untuk pertama kalinya. Pada masa pemerolehan bahasa, anak lebih mengarah pada fungsi komunikasi daripada bentuk bahasanya. Pemerolehan bahasa anak tidak terjadi secara tiba-tiba.Artinya, bahwa dalam pemerolehan bahasa terjadi secara berkesinambungan memiliki suatu rangkaian kesatuan, yang bergerak dari ucapan satu kata sederhana menuju gabungan kata yang lebih rumit dan kompleks.

Istilah pemerolehan (acquisition) berarti proses penguasaan bahasa yang dilakukan oleh anak secara natural pada waktu ia belajar bahasa ibunya (native language). Istilah ini berbeda dengan pembelajaran (learning), yakni proses yang dilakukan dalam tataran yang formal (belajar di kelas dan diajar oleh seorang guru). Dengan demikian, proses dari anak yang belajar menguasai bahasa ibunya adalah pemerolehan, sedangkan proses dari orang umumnya dewasa yang belajar di kelas adalah pembelajaran 
(Dardjowidjojo, 2010 dalam Arsanti, 2014: 2).

Chaer (2003: 167) menyatakan bahwa pemerolehan bahasa atau akuisisi bahasa adalah proses yang berlangsung di dalam otak seorang kanak-kanak ketika dia memperoleh bahasa pertamanya atau bahasa ibunya. Pemerolehan bahasa biasanya dibedakan dengan pembelajaran bahasa. Pembelajaran bahasa berkaitan dengan proses-proses yang terjadi pada waktu seorang kanak-kanak mempelajari bahasa kedua, setelah ia memperoleh bahasa pertamanya. Sehingga, pemerolehan bahasa berkenaan dengan penguasaan bahasa yang pertama.

Parera (1986: 84) juga membedakan memberikan perbedaan antara pemerolehan dan pembelajaran bahasa. Parera mengatakan bahwa pemerolehan bahasa terjadi pada masa bayi sejalan dengan pemerolehan yang lain. Pemerolehan bahasa bermotivasi internal, data bahasa tidak terprogram dan tidak ada guru atau instruktur formal. Sedangkan dalam pembelajaran bahasa, terjadi apabila permormans atau penampilan bahasa pertama sudah tetap. Belajar bahasa bermotivasi eksternal berdasarkan faktor kebutuhan serta manfaat. Belajar bahasa berlaku dalam satu program silabus dan dalam pengajarannya ada guru dan instruktur formal.

Selama pemerolehan bahasa pertama, Chomsky menyebutkan bahwa ada dua proses yang terjadi ketika seseorang memperoleh bahasa pertamanya. Proses yang dimaksud adalah proses kompetensi dan proses performansi. Kedua proses ini merupakan dua proses yang berlainan. Kompetensi adalah proses penguasaan tata bahasa (fonologi, morfologi, sintaksis, dan semantik) secara tidak disadari. Kompetensi ini dibawa oleh setiap anak sejak lahir. Meskipun dibawa sejak lahir, kompetensi memerlukan pembinaan sehingga anak-anak memiliki performansi dalam berbahasa. Performansi adalah kemampuan anak menggunakan bahasa untuk berkomunikasi. Performansi terdiri dari dua proses, yaitu proses pemahaman dan proses penerbitan kalimatkalimat. Proses pemahaman melibatkan kemampuan mengamati atau mempersepsi kalimat-kalimat yang didengar, sedangkan proses penerbitan melibatkan kemampuan menghasilkan kalimat-kalimat sendiri (Chomsky dalam Chaer 2003:167).

Selanjutnya, Chomsky juga beranggapan bahwa pemakai bahasa mengerti struktur dari bahasanya yang membuat dia dapat mengkreasi kalimat-kalimat baru yang tidak terhitung jumlahnya dan membuat dia mengerti kalimatkalimat tersebut. Jadi, kompetensi adalah pengetahuan intuitif yang dipunyai seorang individu mengenai bahasa ibunya (native languange). Intuisi linguistik ini tidak begitu saja ada, tetapi dikembangkan pada anak sejalan dengan pertumbuhannya, sedangkan performansi adalah sesuatu yang dihasilkan oleh kompetensi.

Berkaitan dengan istilah pemerolehan bahasa yang biasanya digunakan pada anak-anak, istilah pemerolehan ini pula dapat digunakan pada orang dewasa yang ingin menguasai bahasa kedua. Upaya pengusaan bahasa kedua oleh orang dewasa dilakukan dengan beberapa tujuan, misalnya untuk memperluas pengetahuan, meningkatkan kemampuan berkomunikasi, dapat beradaptasi dengan dunia luar dan guna mengembangkan kehidupannya. Seseorang juga berusaha memperoleh bahasa kedua sebagai bahasa yang dapat digunakan dalam kehidupan sehari-harinya untuk berbagai kepentingan. Misalnya, kepentingan pariwisata, pendidikan, pekerjaan, ekonomi, sosial, budaya, dan politik. Pemerolehan bahasa kedua bagi orang dewasa tidak secara serta merta, melainkan memerlukan waktu yang cukup lama dan tergantung pada adanya kesempatan untuk menggunakan bahasa kedua, serta faktor-faktor yang mempengaruhi pemerolehan bahasa kedua.

\section{Faktor-faktor yang Pemerolehan Bahasa Kedua}

a) Usia

Sayekti (2001) dalam Arshanti (2014: 4) mengatakan bahwa proses pemerolehan bahasa seorang anak berlangsung secara efektif pada usia di bawah lima tahun (balita). Proses itu secara bertahap terus berlanjut mengikuti perkembangan usia dan pengalamannya. Potensi pemerolehan bahasa pada anak balita tinggi, sehingga potensi itu perlu dioptimalkan, mengingat penguasaan bahasa sangat berpengaruh kepada proses penguasaan yang lain ketika anak memasuki usia sekolah. Jadi, dapat dikatakan bahwa usia balita adalah usia emas dalam pemerolehan bahasa, sehingga pada masa ini harus benar-benar dioptimalkan agar pemerolehan bahasa anak dapat maksimal (Sayekti, 2001) dalam Arshanti, 2014: 4). Pendapat yang sama juga diungkapkan Parera (1986: 84-68) yang mengatakan bahwa anak-anak lebih cepat dan lebih gampang dalam memperoleh bahasa dibandingkan dengan orang dewasa karena anak-anak secara biologis diprogramkan untuk belajar bahasa, sedangkan orang dewasa tidak. Semakin muda seorang anak, maka semakin terampil ia memperoleh bahasa kedua. 
Dari pendapat di atas, dapat diketahui bahwa potensi pemerolehan bahasa pada usia balita sangat tinggi. Jika dihubungkan dengan pemerolehan bahasa kedua, potensi pemerolehan bahasa kedua lebih cepat apabila dilakukan pada usia kanak-kanak. Pemerolehan bahasa kedua pada anak-anak dapat lebih mudah, karena otak anak masih lentur, belum mampu memikirkan banyak hal yang akan mempengaruhi pemerolehan bahasa kedua.

Beberapa penelitian menyimpulkan bahwa penguasaan B2 secara sempurna dapat terjadi jika B2 tersebut dipelajari pada usia kritis (critical period). Patkowsky (1990) mengklaim bahwa semakin dini usia yang mempelajari B2, semakin bagus dan sempurna cara pelafalannya. Dia menyatakan bahwa pemerolehan B2, terutama dalam hal pelafalan (pronounciation) akan berbeda jika dipelajari sebelum dan sesudah usia kritis (critical period). Usia dini tersebut adalah sebelum usia 15 tahun. Di sisi lain, Bialystock (1997) mengungkapkan bahwa umur subjek atau mereka yang mempelajari B2 juga dipengaruhi oleh tingkat kerumitan sistem B2 yang dipelajari tersebut. Artinya jika subjek telah memperoleh atau telah memiliki rasa bahasa pada bahasa pertama atau bahasa ibu (B1), maka pengaruh B1 terhadap B2 akan semakin besar. Karena itu, dia menyatakan bahwa usia kritis (critical period) adalah pada usia 6 tahun. Pada usia ini, subjek yang mempelajari B2 belum terlalu menguasai atau memiliki rasa bahasa B1 dan karenanya sangat baik untuk mempejari B2.

Penelitian Weiyun He (Simpson, 2011: 287) dalam artikelnya yang berjudul "Sosialisasi Bahasa" juga terlihat adanya pengaruh faktor usia terhadap pemerolehan bahasa kedua. He meneliti seorang anak yang bernama Jason yang berasal dari China dan pada umur tiga tahun beremigrasi ke Amerika bersama orang tuanya. Pada masamasa awal berada di Amerika, Jason belum mampu menggunakan bahasa Inggris dengan baik, tetapi dalam perkembangan selanjutnya Jason menjadi sangat fasih dalam berbahasa Inggris dan menjadi murid berprestasi di sekolah.

Contoh kasus berkaitan dengan pengaruh usia terhadap pemerolehan bahasa kedua sering penulis jumpai dalam kehidupan sehari-hari. Berdasarkan hasil pengamatan penulis terhadap beberapa orang yang keluar dari pulau Sumba untuk mencari pekerjaan dan mereka menemukan jodoh di tempat kerja tersebut, Misalnya Bali, Mataram, Pulau Jawa, dll. Anak hasil pernikahan mereka sehari-hari menggunakan bahasa Indonesia yang merupakan bahasa pertama atau bahasa ibu. Berdasarkan hasil pengamatan penulis, anak-anak mereka pada saat kembali ke Sumba dengan mudah dan fasih menggunakan bahasa Sumba dalam waktu yang relatif singkat. Umur anak pada saat kembali ke Sumba berkisar 12 tahun ke bawah. Usia ini merupakan usia emas bagi anak untuk memperoleh bahasa sehingga mereka mudah mengusai bahasa Sumba.

Contoh kasus lain yang didapatkan oleh penulis setelah melakukan wawancara dengan seorang ibu yang berasal dari Pulau Jawa, bekerja di Kupang dan memiliki suami orang Sumba. Dari hasil wawancara ini diketahui bahwa dalam berkomunikasi sehari-hari anak mereka menggunakan bahasa Kupang. Sehingga, bahasa Kupang ini merupakan bahasa pertama anak. Ketika kembali ke Sumba, dalam waktu yang relatif cepat anak dapat menggunakan bahasa Sumba dengan baik dan sangat fasih. Sedangkan, ibunya yang orang Jawa hanya bisa mengerti bahasa Sumba tetapi tidak mampu menuturkannya. Usia anak ini pada saat kembali ke Sumba kira-kira masih di bawah usia emas.

Dari beberapa penelitian dan contoh kasus di atas sangat jelas sekali bahwa bahasa kedua lebih mudah diperoleh jika dipelajari pada usia kritis. Bahkan hampir semua peneliti menyetujui bahwa bahasa kedua dapat diperoleh secara total seperti penutur asli jika dipelajari sebelum usia 12 tahun.

\section{b) Lingkungan dan Kebiasaan}

Lingkungan memiliki pengaruh yang sangat besar dalam proses pemerolehan bahasa kedua. Kebiasaan-kebiasaan seseorang menggunakan bahasa kedua dalam suatu lingkungan akan membawa dampak positif dalam pemerolehan bahasa kedua. Pemerolehan bahasa kedua dalam lingkungan pemakai bahasa kedua merupakan fenomena pemerolehan bahasa yang bersifat kompleks, artinya dalam pemerolehan bahasa ini pembelajar tidak hanya memahami makna dari kata-kata atau kalimat, tetapi lebih dari itu seseorang berusaha memahami maksud dari suatu peristiwa komunikasi. Kesalahankesalahan penggunaan bahasa kedua dalam suatu peristiwa komunikasi akan sangat membantu si pembelajar dalam menguasai bahasa kedua. Karena, ketika si pembelajar tersebut keliru dalam menggunakan bahasa kedua, maka orang yang ada dalam lingkungan bahasa kedua tersebut akan langsung memperbaikinya dengan penggunaan yang tepat sesuai dengan konteks. Keberhasilan pemerolehan bahasa kedua dalam suatu lingkungan sangat dipengaruhi oleh stimulus dan 
respon.

Teori yang sangat berpengaruh terhadap pemerolehan bahasa kedua dalam suatu lingkungan adalah teori behaviorisme dan teori kognitivisme. Menurut pandangan teori behaviorisme bahwa bahasa akan dapat diperoleh dan dikuasai karena faktor kebiasaan. Seorang anak kecil akan dapat menguasai bahasa bila semakin sering dia mendapat stimulus dari luar yang membuat dia tertarik untuk mencoba berkomunikasi dengan dengan memberikan respon melalui gayanya sendiri. Konsep dasar teori behaviorisme dilandasi anggapan bahwa seseorang setelah lahir tidak memiliki apa-apa, sehingga dalam pemerolehan bahasa lingkungan sangat berperan penting. Dengan kata lain, lingkunganlah yang banyak memberi sumbangan kepada seseorang sehingga dapat memperoleh bahasa.

Sebagaimana halnya pada teori behaviorisme, begitu juga dengan teori kognitivisme. Menurut Littlewood (1984) dalam (Purba, 2013: 2) bahwa minat merupakan suatu faktor yang berperan dalam mencapai proses internal anak. Namun seharusnya kita tidak melupakan bahwa lingkunganlah yang menstimulasi proses-proses internal itu. Lingkungan akan menyediakan berbagai materi terhadap anak dalam pemerolehan bahasanya di mana ia berada. Hal ini yang sama juga dikemukakan oleh Subyakto (1992) bahwa anak lahir sudah memiliki prosedur-prosedurserta kaidah bahasa yang memungkinkan seseorang anak mengolah data linguistiknya di lingkungannya.

Terlepas dari teori behavariosme dan kognitivisme, peranan lingkungan dalam pemerolehan bahasa sangat besar. Daulay (1985) dalam Purba (2013: 3-4) mengemukakan bahwa kualitas lingkungan bahasa teramat penting bagi seorang pembelajar bahasa untuk bisa berhasil dalam belajar bahasa baru. Pengenalan yang dilakukan oleh guru di dalam kelas akan menentukan proses belajar bahasa yang dialami oleh pembelajar. Disamping itu, Huda (1987) dalam Purba (2013: 3-4) mengemukakan juga, bahwa "hipotesis input Krashen" menyatakan bahwa pembelajaran memperoleh bahasa kedua hanya dengan satu cara, yaitu dengan jalan mengerti maksud pesan yang sampai kepadanya. Dengan kata lain, pembelajar bisa berbahasa kedua karena telah mendapat input yang bisa dimengerti maksudnya. Pembelajar bisa mengerti wacana yang berisi tata bahasa yang tidak diurutkan penyajiannya (secara alamiah) karena adanya bantuan konteks, pengetahuannya tentang kehidupan dan alam sekitarnya, dan kemampuan linguistik yang telah dikuasai sebelumnya.

Pengaruh lingkungan terhadap pemerolehan bahasa kedua sangat besar. Hal ini dapat dilihat dari contoh kasus di Selandia baru, dimana seorang pelajar asing sekarang ini tidak lagi dipersyaratkan untuk memiliki nilai ujian TOEFL, tetapi para pelajar itu tidak diasramakan untuk menghindari mereka berkumpul dengan teman dari satu negara atau pemakai bahasa yang sama dengan dirinya. Mereka dibaurkan dengan masyarakat setempat yang memaksa para pelajar itu mau tidak mau harus berkomunikasi dengan bahasa Inggris yang dipakai di Selandia Baru sebagai bahasa sehari-hari. Karena kebiasaan yang terus-menerus baik di kampus, rumah, pasar, taman hiburan, stasiun, terminal dan tempattempat lainnya, pada akhirnya para pelajar tersebut dapat dengan sempurna menguasai bahasa Inggris. Hal ini menandakan bahwa faktor kebiasaan dan faktor lingkungan sangat berpengaruh besar terhadap keberhasilan seseorang memperoleh dan menguasai bahasa kedua (Onchera, 2013).

Beberapa penelitian membuktikan bahwa lingkungan dan kebiasaan memiliki pengaruh dalam pemerolehan bahasa kedua. Hasil penelitian Weiyun He (Simpson, 2011: 294) menunjukkan bahwa pada saat awal Jason pindah ke Amerika kemampuan berbahasa Inggrisnya sangat kurang, sehingga orang tuanya meningkatkan potensi penggunaan bahasa Inggris di rumah. Pengaruh kebiasan-kebiasaan menggunakan bahasa Inggris di rumah menyebabkan Jason menjadi sangat fasih dan mahir dalam menggunakan bahasa Inggris. Namun, dampak negatif dari peningkatan penggunaan bahasa Inggris di rumah adalah Jason menjadi lupa dengan bahasa China. Hal ini terjadi karena di rumah hanya neneknya yang menggunakan bahasa China dan itupun dilakukan seminimal mungkin. Dari hasil penelitian ini, dapat disimpulkan bahwa penggunaan bahasa kedua secara terus menerus dalam suatu lingkungan memberikan pengaruh yang besar dalam pemerolehan bahasa ke dua.

Penelitian Milon (1975) dalam Purba (2013: 10) menunjukkan adanya pengaruh lingkungan terhadap pemerolehan bahasa kedua. Dalam penelitian ini diketahui bahwa seseorang anak keturunan Jepang berusia tujuh tahun yang bermigrasi ke Hawai lebih cepat memahami bahasa Inggris Kreol Hawai yang diperolehnya dari kawan-kawan sebayanya, jika dibandingkan 
dengan Bahasa Inggris standar yang dipelajarinya dari guru di sekolah.

Hasil wawancara penulis terhadap seorang ibu yang berasal dari Jawa, bersuamikan orang Sumba dan untuk beberapa saat tinggal di Kupang. Ketika pindah ke Sumba, anaknya dengan cepat mengusai bahasa Sumba. Di rumah mereka tidak menggunakan bahasa Sumba. Bahasa itu diperoleh anaknya melalui temanteman bermainnya. Ibu ini menghabiskan waktunya di kantor, sehingga kurang berinteraksi dengan masyarakat sekitar. Bahasa Sumba yang dimiliki ibu ini hanya sekitar menyambut tamu atau mempersilahkan tamu yang datang ke rumahnya. Contoh kasus lain yang penulis amati, yaitu penguasaan bahasa Sumba bagi orang-orang Jawa atau Bima yang berjualan di Pasar. Orangorang Bima dan Jawa yang berjualan di Pasar tidak perna mempelajari secara khusus bahasa Sumba, tetapi melalui interaksi dengan pembeli mereka dengan mudah menguasai bahasa Sumba.

Dari beberapa penelitian dan contoh kasus di atas, dapat disimpulkan bahwa apabila seseorang ingin menguasai bahasa kedua, maka orang tersebut harus tinggal, berkomunikasi dan berinteraksi secara langsung dengan orang-orang yang dalam berkomunikasi sehari-hari menggunakan bahasa kedua. Pembelajar juga harus menggunakan bahasa kedua secara terusmenerus dalam waktu yang lama.

\section{c) Pengaruh Bahasa Pertama terhadap} Bahasa Kedua

Struktur bahasa pertama yang telah terpola dalam pikiran pembelajar dalam banyak kasus mempengaruhi pemerolehan bahasa kedua. Hal ini disampaikan oleh Krashen (Onchera, 2013) yang menyatakan bahwa hipotesis urutan alamiah memandang bahwa apabila terdapat persamaan urutan atau struktur gramatikal antara belajar B1 dengan belajar B2 yang dipelajari, maka dengan muda bahasa kedua akan lebih cepat diperoleh. Fitri (2015: 2) mengatakan bahwa jika salah satu pembicara masyarakat mencoba untuk menggunakan bahasa lain selain bahasa mereka sendiri, maka bahasa yang mereka gunakan akan merubah bentuk seperti pada bahasa kedua. Jadi, fitur dari B1 yang digunakan oleh pembicara seperti cara, gaya, dan struktur bahasa pertama secara tidak langsung mengikuti bahasa kedua.

Contoh kasus yang diamati oleh penulis, terhadap masyarakat Sumba yang berkomunikasi sehari-hari menggunakan bahasa kedua (bahasa Indonesia). Dari pengamatan penulis diketahui bahwa struktur bahasa pertama sangat berpengaruh terhadap tranfer bahasa kedua.
Ketika seseorang yang berlatar belakang B1 bahasa Sumba pada saat menuturkan B2 mengikuti struktur B1. Hal ini dapat dilihat dalam contoh berikut.

Contoh 1. Tuturan Bahasa Indonesia dengan Struktur bahasa Sumba
A : Sudah makan kamu?
B : sudah makan saya.

Contoh 1. Tuturan Bahasa Indonesia dengan Struktur bahasa Indonesia
A : Kamu sudah makan?
B : Saya sudah makan.

\section{Contoh 2. Tuturan Bahasa Indonesia dengan} Struktur bahasa Sumba
A : sedang apa kamu?
B : sedang belajar saya.

\section{Contoh 2. Tuturan Bahasa Indonesia dengan} Struktur bahasa Indonesia
A : Kamu sedang apa?
B : Saya sedang belajar.

Dari contoh 1 dan contoh 2 di atas dapat dilihat bahwa kalimat dalam bahasa Indonesia yang dituturkan masih dipengaruhi oleh struktur bahasa pertama. Sehingga, dapat dikatakan bahwa struktuk bahasa salah satu faktor yang mempengaruhi pemerolehan bahasa kedua.

\section{d) Motivasi}

Salah satu faktor yang mempengaruhi pemerolehan bahasa kedua adalah motivasi. Dengan adanya motivasi yang kuat, maka pembelajar bahasa kedua akan berusaha memperoleh bahasa kedua. Motivasi mengacu pada keseluruhan proses yang dilakukan dalam upaya mengusai bahasa kedua dengan tujuan tertentu. Misalnya, seseorang berusaha menguasai bahasa kedua dengan tujuan untuk mendapat kepuasan diri, untuk mendapatkan pujian, penghargaan dan pengakuan dari orang lain, untuk meningkatkan perekonomian, agar mampu bersaing dalam dunia politik, mampu beradaptasi dalam lingkungan kerja yang baru, mampu bersaing sesuai dengan tuntutan zaman.

Dalam teori pemerolehan bahasa kedua (second language acquisition), motivasi biasanya dipahami sebagai serangkaian faktor, termasuk aspirasi untuk mencapai tujuan tertentu melalui belajar bahasa, kesediaan untuk melakukan dan mempertahankan usaha dalam rangka mencapai tujuan, serta sikap terhadap perolehan bahasa dan masyarakat yang menggunakannya (Gardner, 1985a, 2001b; Klein, 1986; Dörnyei \& Csizér, 2005) dalam Ying, dkk (2013: 3). Klein (1986) menunjukkan empat faktor yang merupakan motivasi untuk belajar bahasa asing: social 
integration (belajar bahasa dalam rangka untuk dapat berpartisipasi dalam kehidupan masyarakat yang berbicara dengan menggunakan bahasa tersebut). Misalnya, communicative needs (tujuan pembelajaran bahasa), attitude (orientasi subjektif terhadap bahasa yang dipelajari dan orang-orang yang menggunakannya), dan education (belajar bahasa asing sebagai bagian dari konsep pendidikan wajib dalam suatu masyarakat tertentu). Diferensiasi antara integrasi sosial dan kebutuhan komunikatif dikaitkan dengan pembagian yang diusulkan oleh Gardner (1985a, 2001b) menjadi integrative dan instrumental attitudes (Ying, dkk, 2013: 3).

Integrative attitude diasumsikan untuk menciptakan hubungan yang positif antara bahasa yang sedang dipelajari dan masyarakat yang menggunakan bahasa tersebut. Ini berarti keinginan seseorang tidak hanya untuk menjadi pembicara yang kompeten tetapi juga untuk merasakan budaya yang terhubung dengan bahasa, untuk memahami berbagai aspek, untuk bertemu dengan orang dan berinteraksi dengan mereka, atau bahkan ingin bergabung dengan kehidupan komunitas mereka. Sikap seperti ini juga terkait dengan cita-cita untuk mencapai tidak hanya keadaan bilingualisme relatif, tapi juga keadaan bikulturalisme relatif. Bahasa kedua peserta didik dengan sikap integratif mencoba untuk menghidupkan bahasa kedua dan budaya menjadi unsur pembentukan identitas mereka (Gardner, 1985a, 2001a; Dörnyei \& Csizér, 2005).

Varian lain sikap motivasi adalah instrumental attitude. Dalam hal ini kasus bahasa kedua dan budaya diperlakukan lebih sebagai alat membantu untuk mencapai tujuan pribadi, seperti mendapatkan pekerjaan yang menarik, meningkatkan kemungkinan seseorang di pasar kerja atau memperbaiki status sosial seseorang untuk meningkatkan pendidikan yang lebih baik atau mendapatkan keterampilan ekstra. Belajar bahasa kedua sering disertai oleh jenis sikap ini karena pengetahuan tentang bahasa asing juga berguna dalam memecahkan berbagai masalah praktis, seperti mendapatkan akses ke literatur spesialis atau bertahan selama kunjungan ke luar negeri yang tidak semua orang tahu bahasa asing tersebut (Gardner, 1985a, 2001b; Riemer, 2003) dalam (Ying, dkk, 2013: 4).

Untuk mengetahui pengaruh motivasi terhadap pemerolehan bahasa kedua , maka Ying, dkk, melakukan penelitian kepada mahasiswa yang mempelajari bahasa Mandarin sebagai bahasa kedua. Hasil penelitian Ying, dkk menunjukkan bahwa motivasi instrumental mahasiswa berusaha mempelajari bahasa Mandarin adalah agar dapat memperoleh pekerjaan yang menjanjikan dikemudian hari. Motivasi instrumental menekankan pada tujuan untuk meningkatkan penghargaan sosial maupun ekonomi melalui pencapaian atau prestasi. Dari hasil penelitian ini juga diketahui bahwa mahasiswa Sastra Mandarin dari suku non-China lebih termotivasi belajar Bahasa Mandarin baik secara integratif, instrumental dan intensitasnya. Responden yang bukan berasal dari suku China berusaha belajar dengan keras ketika menemui kesulitan dalam mempelajari bahasa Mandarin segera bertanya kepada dosen untuk meminta penjelasan. Hal ini disebabkan mereka bukan berasal dari keluarga yang menggunakan Bahasa Mandarin sebagai bahasa pertama. Sementara bagi mahasiswa keturunan China, bahasa Mandarin bisa jadi bukan merupakan bahasa kedua.

Terkait dengan pengaruh motivasi terhadap pemerolehan bahasa kedua, juga disampaikan oleh He (Simpson, 2011: 294) yang meneliti seorang anak yang berasal dari China, yang pada umur tiga tahun beremigrasi ke Amerika. Dari hasil penelitian ini diketahui bahwa Jason berusaha menguasai bahasa China yang dalam hal ini telah merupakan bahasa keduanya dengan tujuan suatu saat nanti dia ingin membangun karir atau mendapatkan pekerjaan di China. Sedangkan, temannya yang sedang berusaha mempelajari bahasa China memiliki motivasi mempelajari bahasa China karena pacarnya adalah orang China.

Contoh kasus yang penulis amati terkait dengan pengaruh motivasi terhadap pemerolehan bahasa kedua, yaitu di tempat kerja penulis terdapat orang Jerman yang bekerja di bidang peningkatan mutu pembelajaran. Untuk dapat berinteraksi dan menciptakan suatu komunikasi yang baik dalam beradaptasi dengan lingkungan dan masalah pekerjaan, maka mereka harus menguasai bahasa Indonesia. Cara peningkatan pengusaan bahasa Indonesia dilakukan dengan berkomunikasi secara langsung dan selalu membawa kamus dengan tujuan apabila ada katakata atau tuturan yang kurang dipahami dapat langsung dikomunikasikan makna dan maksud tuturan tersebut sesuai konteks dan yang terdapat dalam kamus.

Perkembangan zaman yang semakin mengglobal ini menuntut setiap individu untuk dapat bersaing dalam dunia kerja. Persaingan ini dapat berjalan dengan lancar apabila setiap individu memiliki pemahaman dan pengertian 
yang sama dalam berkomunikasi. Dalam hal ini menuntut manusia untuk memiliki lebih dari satu bahasa.

\section{Kesimpulan}

Bahasa kedua merupakan bahasa yang dipelajari oleh seorang anak setelah menerima dan mempelajari bahasa yang diajarkan oleh ibunya atau bahasa yang diperoleh setelah mengenal dan menguasai bahasa pertama yang digunakan dalam keluarga. Dalam pengertian lain, bahasa kedua adalah bahasa yang didapatkan dari lingkungan di luar rumah, seperti lingkungan sekolah, tempat bermain, dan lingkungan sosial.

Pemerolehan bahasa kedua tidak terjadi secara serta merta, artinya bahwa pemerolehan bahasa kedua memerlukan waktu yang cukup lama, apalagi jika yang mempelajari bahasa kedua tersebut adalah orang dewasa. Pemerolehan bahasa sangat dipengaruhi oleh beberapa faktor, yaitu usia (anak yang masih berusia emas akan dengan mudah menguasai bahasa kedua), lingkungan dan kebiasaan (penggunaan bahasa yang secara terus-menerus dalam suatu interaksi sosial sangat mempengaruhi pemerolehan bahasa kedua), struktur gramatikal Bi dan B2 (apabila terdapat persamaan struktur antara B1 dan B2, maka bahasa kedua lebih muda diperoleh), motivasi (adanya tujuan tertentu sebagai motivasi dalam memperoleh bahasa kedua merupakan unsur yang sangat penting dalam pemerolehan bahasa kedua).

\section{Daftar Pustaka}

Adero, Laban Mak'obila and Paul Onsare Onchera. (2013). English Language Teachers' Choice of Second Language Teaching and Learning Theories In Eldoret municipality, Kenya. International Research Journals. Published by Educational Research, IV (10), 693-701.

Arshanti, Meilan. (2014). Pemerolehan bahasa pada anak: kajian psikolinguistik. Jurnal PBSI, III (2).

Bialystock, E . (1997). The Structure of Age: in Search of Barriers to Second Language Acquisition. Second Language Research, XIII (2), 116137.

Chaer, Abdul. 2003. Psikolinguistik:Kajian Teoretik. Jakarta: Rineka Cipta.

Dardjowidjojo, Soenjono.2005 Psikolinguistik:
Pengantar Pemahaman Bahasa

Manusia. Jakarta: Yayasan Obor.

Fitri, Aulia. (2015). Pengaruh Bahasa Ibu Terhadap Penggunaan Bahasa Asing: Kesalahan Transfer Secara Pragmatics. Padang: Universitas Negeri Padang, 1-12.

Onchera, Paul Onsare. (2013). English Language Teachers' Choice of Second Language Teaching and Learning Theories In Eldoret municipality, Kenya. International Research Journals. Published by Educational Research, IV (10), 693-701.

Parera, Yos Daniel. 1986. Linguistik Edukasional. Jakarta: Erlangga.

Patkowsky, M. (1990). Age and Accent in a Second Language: A Reply to James Emil Flege. Applied Linguistics, XI, 73-89.

Purba, Andiopenta. (2013). Pengaruh Lingkungan Bahasa dalam Pemerolehan Bahasa Kedua. Pena, III (1).

Simpson, James. (2011). The Routledge Handbook of Applied Linguistik. Taylor and Francis Group: London and New York.

Sugiono. (2005). Metode Penelitian Kuantitatif, Kualitatif, dan $R \& D$. Bandung: Alfabeta.

Syamsudin dan Damaianti. (2009). Metode Penelitian Pendidikan Bahasa. Bandung: PT. Remaja Rosda Karya.

Ying, Yi, dkk. (2013). Motivasi Belajar Bahasa Mandarin Sebagai Bahasa Kedua. Humaniora, IV (2). 